All Azimuth V5, N2, Jul. 2016, 91-94

\title{
Hard Power versus Soft Power or a Balance between the Two?*
}

Peter Volten

University of Groningen

\begin{abstract}
Many things have changed in Turkey within the last decade, but also in Brussels as to the political practises. This commentary seeks to answer whether Turkey and the EU can find and maintain a sensible balance between toughness and empathy, between considerations of hard power and soft power. Turkey is obviously an essential, regional player both economically and militarily. Geopolitics may not appear high on the agenda of the EU, but the situation in the Middle-East simply could not and cannot be ignored as a geopolitical challenge, one that might beg for acting in concert with Turkey. On the other side, Europe represents an attraction and example based on a long history and struggle for material wealth, technological and scientific progress as well as for the accomplished degree of democracy and the rule of law. More recently, however, EU soft power suffers a number of setbacks. We disown our most basic values of soft power and will lose impact in promoting a just, democratic order in the world. If the EU and its member states fail to recover from this set-back, we risk to fall back in the hard power game, also with potential and aspiring states.
\end{abstract}

Keywords: Turkey, European Union, soft power, hard power, European enlargement

Just over ten years ago my Centre for European Security Studies started a programme in Turkey concerning democratisation of security and defence policy. The Dutch government hold the Presidency of the European Union and considered such a programme a positive contribution to the Turkish efforts to become a member state and a positive response to the reforms of the ruling and, indeed, stable government. The Hague sponsored us and we ran the programme nine years trying to further democratic decision-making in defence matters, political oversight by the ministry of Defence and parliament, defence budgeting and auditing and the role of the military in politics was supposed to change. The message from Brussels was that civil-military relations in Turkey needed to be further aligned to practises in the EU.

Well, since then many things have changed in Turkey including the role of the military, but also in Brussels as to the political practises. Ten years later one might ask and even doubt whether the relations between Turkey and the EU have changed for the better as envisaged by, for example, the Dutch government and Ankara at the time. Some - individuals of governments - argued that Turkey could join the EU somewhere during the 2020s and the Turkish government enjoyed the support of a vast majority of the people. Over the years this kind of optimistic mood has not been maintained. Relations became more complex; the tone

Peter Volten, Professor Emeritus, University of Groningen, the Netherlands. Email: p.m.e.volten@rug.nl

*This paper is presented at the 5th Turkey-Europe Forum, TASAM, 20-22 April 2016, Istanbul. 
of the interlocutors tougher. Politics always deals with power, but it makes a big difference whether power is a tool in a Hobbesian or Kantian manner and whether power relations exist in a Hobbesian or Kantian political culture. Allies can be tough for each other, but as long as they share insights, strategies, values and expectations, the face of hard power may become more friendly and non-material considerations may carry the day. But there is no guarantee and we have to fight hard for maintaining a common course. This is a major question for the EU and Turkey as well as for the relations between the two. Can we find and maintain a sensible balance between toughness and empathy, between considerations of hard power and soft power?

I start with hard power and can be relatively brief since it is a familiar concept in international relations. Economic relations can be tough, even between friends, but they represent in principle a win-win solution. The EU wins by enlarging the internal market and Turkey wins by considerably opening up Turkey's market for further expansion. The economic performance of Turkey during the past 10-15 years has been truly impressive, certainly when compared with EU growth since 2008.

As to the significance of military power, the views within the EU - with the exception of France and the UK, perhaps - and Turkey are probably not as close as in the economicfinancial case. National defence is a subject that in most EU countries is met with disinterest. Even the willingness to defend the West in the context of NATO and/or EU allies is shockingly low in some countries. Defence expenditure of most EU member states is down to around 1 per cent of GDP, a horrendously low security insurance. Nonetheless, the EU spends almost $\$ 300$ billion on defence, but its organisation is so inefficient that no country can field a robust force of sorts for a longer period of time. This fragmentation of capabilities seriously hampers the output of defence efforts. But nobody really does something about it, often in name of keeping so-called national sovereignty. Sovereignty in an interdependent world is a moot concept, though, and if sovereignty leads to military powerlessness, what is the purpose of the defence effort? Indeed, military operations have been disappointing like the interventions in Iraq or Afghanistan. Without support on the ground - political and/or military - interventions and proxy wars are hazardous and defeat always looms large. As we see in Syria today, terrorism has become part of the answer against bombing IS; a challenge that cannot be meet with conventional forces of the allies. Moreover, without their own boots on the ground, the Western powers are dangerously dependent on a range of unwieldy rebels and fighters as well as on some dubious allies.

Turkey is obviously an essential, regional player vulnerable to the fighting on its borders. Military power is a crucial tool in directly providing territorial integrity and security for its population. For these reasons the EU and its member states should have shown greater interest in Turkey's membership in the past. Geopolitics may not appear high on the agenda of the EU, but the situation in the Middle-East simply could not and cannot be ignored as a geopolitical challenge, one that might beg for acting in concert with Turkey. Military solutions seem to be elusive; yet the proximity of Turkey and its military capabilities together with political-diplomatic leverage of Europe should have figured prominently in considering closer cooperation and potential membership. Yet, geopolitical sense was pretty weak in the EU, even in traditionally Realist France where Sarkozy since 2005 explicitly ruled out these options. 
If then the Europeans are not the hard power players like followers of Mars, how well are the Europeans coming from Venus according to Robert Kagan, playing the soft power game?Soft power is primarily based on non-material capacities like culture, values, historical record or policies. Unlike hard power like strength, you do not have soft power, but it is granted by someone else in a relationship with you. The other sees the kind of power as attractive, something to acquire for oneself. The European experiment since 1957 proved to be a tremendous success and it readily expanded throughout the European continent. Of course, economic growth and prosperity were also reasons for expansion. Yet, the 'Idea of Europe' went further than material wealth, notably in the Soviet dominated countries where people like Vaclav Havel and members of Charter 77 aspired to the way of living under democratic rule and the rule of law as practiced in Western-Europe. These former communist countries were willing to accept conditionality put forward by the EU and even considered this as a means to speed up the process of transformation. In that sense, conditionality was not a traditional power game of coercion; but rather a form of assistance to enter unchartered waters. On the other side, the EU appeared to be a credible player loyal to its values and declared policies. It extended the prospect of membership to all (five) Central-European countries plus the (three) Baltic states; not just two or three. Membership is in principle eligible for all European states and there was no valid reason for preferential selection of presumably better candidates. How could you say that, for example, Romania or Bulgaria had not suffered as much as Poland and did not deserve an equal chance for a different life?

So, attraction, willingness to work hard on reform, fairness and credibility were all essential ingredients for cooperation and integration in Europe rather than another round of continental power politics. The post-war practice of negotiation on the basis of agreement and desire for inclusiveness was respected. However, there is more than this institutionalised habit under the auspices of the European Communities/Union. Europe represents an attraction and example based on a long history and struggle for material wealth, technological and scientific progress as well as for the accomplished degree of democracy and the rule of law. Centuries have gone by before the state of art of liberalism, individual responsibility, prosperity, freedom and equality had taken root and could (start to) flourish. Enlightenment did not come overnight; nor did physics or technology. Huge obstacles, like repression or intolerance, had to be cleared; unparalleled drama's, like nationalism, fascism and communism, two world wars and one Cold War had to be overcome. The liberal victories over evil movements have been won the hard way. Evidently, success of the EU goes well beyond its seventy year existence. Soft power has a long history and slowly become an asset of strength.

A similar experience with soft power has not been part of Turkish history. Military prowess, pride and power characterize the Ottoman empire and the establishment of the Republic after WW I. The liberation of men and individual responsibility as treasures of the Enlightenment and the growing consensual power about democratic and constitutional/ legal institutions at home are not characteristic of modern history in Turkey. Nor is soft power prominent in its external relations. Ten years ago, some sympathetic observers of EU-Turkey rapprochement were disappointed that there were not many outspoken European diplomat/advocates for the Turkish case in Brussels at the time that Ankara was serious about reforming democratic and constitutional rule. Developments since then have not particularly strengthened the hands of these advocates. In brief, there is a discrepancy between the views on the usefulness of hard power, in particular military power, in Ankara and Europe, but 
there is a considerable gap between the two sides regarding the substance of soft power and the utility and benefits of soft power in our interdependent world. In such a world, relational power has becomes infinitely more important than during the days of the East-West divide. The shrinking, interdependent world forces us to seek inclusiveness rather than nationalist, inward-looking views and exclusiveness. This may be Putin's wish, at least his behaviour, but he and his system are unlikely to play a significant role in shaping the international order. Putin is unable to balance hard and soft power; as such he resembles the $19^{\text {th }}$ century tsar, both at home and abroad. We always have to guard democracy against its enemies. It is never a done deal.

Europeans must fear an ill-fated slippage of standards for the good life as Aristotle described the moral objective of the state. Again, it is never a done deal. Today, fear for globalisation; fear for loss of national identity; fear for emerging economic powers and so on are factors that crudely interfere with exemplary behaviour and Western soft power. Worse, these are easy themes to explore by populists. Still worse, governments have no answers and are reluctant to formulate some. Leaders fear the public polls and often follow them rather challenge popular views. They seek solutions in vague compromises or even in referenda laying responsibility back on the voters. It is a dubious tool certainly for resolving complex issues, not to mention international questions. For example, a mere 32 percent of the Dutch electorate voted in the case of the EU agreement with Ukraine. Sixty per cent opposed the agreement. That means that twenty per cent of the total electorate represented the majority. The organisers, who are against the EU, simply used the public mood against expansion of the EU against the EU itself. They do not care a bit about Ukraine. Meanwhile, they claimed that 'the people' -and thus, democracy- have clearly indicated what the government should do: renounce the agreement. Poor Ukraine and poor people who believed in Europe's soft power and in the Dutch democracy. We actually renounced our values and undermined their credibility.

This example does not stand alone: what about Brexit? What about Hungary that claims to be protestant/catholic and refuses Muslim immigrants? What about Poland changes its constitution unconstitutionally? How can it criticise Germany for showing moral leadership in the refugees drama? What about the lack of a refugee policy, to begin with? I can go on, but the point should be clear. Our soft power suffers a number of setbacks. We disown our most basic values of soft power and will lose impact in promoting a just, democratic order in the world.

This is not just an ephemeral problem. The European societies at large suffer from a lack of responsibility for maintaining the accomplishments. People talk about rights including freedom of speech, social security, 50 per cent plus one as democratic, your view as laymancitizen is as important as the one of experts, criterion to judge truth is measurement, not quality and so on. These people are not fighting for what they inherited in order to retain it. They assume the good life as a concern of the state, not theirs. Nationalists exclude others and do not unite societies, they disunite. They do not support the rules of pluralism and the truth of EU beauty, namely unity in diversity. This is the more profound problem of the EU soft power. If we lose this asset what can we hope for in world politics? There is no-one else to do this job as a non-threatening power. If the EU and its member states fail to recover from this set-back, we risk falling back in the hard power game, also with potential and aspiring states. A prospect we should resist. 